\title{
Seslerio uliginosae-Scorzoneretum purpureae (Festuco-Brometea class) in the Nida Basin (Małopolska Upland) after 90 years
}

\author{
Krystyna Towpasz, Alina Stachurska-Swakoń* \\ Institute of Botany, Jagiellonian University, Kopernika 27, 31-501 Kraków, Poland
}

\section{Abstract}

Seslerio uliginosae-Scorzoneretum purpureae is the only xerothermic community of the Festuco-Brometea class, where a rare species known as Sesleria uliginosa occurs in Poland. A couple of sites hosting this association in the Nida Basin were described in the 1920s and 1950s. All these stands are now situated in the areas designated as xerothermic nature reserves. The study aimed at describing the present-day characteristics of this rare association, the most likely being endemic in Poland, as well as the changes that have occurred in it. The species diversity and the contribution of xerothermic plants have decreased significantly in terms of their number and cover coefficient. Some of the diagnostic species of the association have become extremely rare. Sesleria uliginosa is the only one without visible changes in their dominant position in the community. Mosses, that have played a significant role before, were among the vanished species. At the same time, an increase in number and cover of mesophilous meadows species was observed. Mesophilous grasses belong to the group of species growing in significance in the phytocoenoses. The observed changes in species composition were reflected in a statistically significant increase of nitrogen indicator value. The slow process of succession observed in the Seslerio-Scorzoneretum purpureae could be attributed to the lack of appropriate land use, e.g. mowing and grazing that have been ceased in the nature reserves.

Keywords: Sesleria uliginosa, gypsum grasslands, xerothermic grasslands, species diversity, succession, steppe reserves, ecological indicators, Nida Basin

\section{Introduction}

Sesleria uliginosa Opiz is a north-central European grass species occurring mainly in the lowlands and uplands of Europe [1]. The species is recorded in the red lists of vascular plants due to its rare occurrence and the considerable threat to habitats, in which this species occurs: e.g. in Poland, Slovakia, Czech Republic, Latvia, and Romania [2-4]. It could be found in mire vegetation or wet meadows, and rarely in dry calcareous or gypsum grasslands. The rich fen communities with this taxon are classified within the Caricetalia davallianae order as Seslerietum uliginosae (Hungary [5], Slovakia [6-8]) or Caricetum davalianae (Slovakia [9-11], Romania [12]). In Bulgaria the species was found in the Junco subnodulosi-Schoenetum nigricantis association [13]. It could occur also in Molinietum caeruleae (Molinietalia order) as it was found in the Vienna Basin [14] and Scandinavia [15]. Dry calcareous grasslands with Sesleria uliginosa are rarely found [11] and are classified

*Corresponding author. Email: alina.stachurska-swakon@uj.edu.pl

This is an Open Access digital version of the article distributed under the terms of the Creative Commons Attribution 3.0 License (creativecommons.org/licenses/by/3.0/), which permits redistribution, commercial and non-commercial, provided that the article is properly cited. as Deschampsio mediae-Seslerietum uliginosae [16], or are placed in the Bromion erecti alliance of the Festuco-Brometea class [17].

Sesleria uliginosa rarely occurs in Poland. It is known from the Małopolska Upland and a few localities occur in the Śląsko-Krakowska Upland [18]. It is encountered in two types of habitats, that are extreme in terms of humidity: wet habitats (which include fens from the Caricetalia davallianae order and wet meadows from the Molinietalia order) and dry habitats (xerothermic grasslands of the Festuco-Brometea class). The presence of wet meadows from the Molinietalia order with the contribution of Sesleria uliginosa in the area of the Małopolska Upland, was emphasized by Medwecka-Kornaś [19] who, on the basis of representative relevés, described them provisionally as "the community with Sesleria uliginosa". Later, communities from the Caricetalia davallianae order were studied in detail by Głazek [20,21]. Towpasz and Stachurska-Swakoń [22] studied the extant sites of this species in fen communities, as well as changes that had occurred within them after 25 years. Recently, the occurrence of wet meadows with Sesleria uliginosa (Molinietalia order) was reported from the Śląsko-Krakowska Upland [23].

The association Seslerio uliginosae-Scorzoneretum purpureae was recognized as the only xerothermic community in Poland where Sesleria uliginosa occurs (placed in the CirsioBrachypodion pinnati alliance in the Festucetalia valesiacae order of the Festuco-Brometea class). The community was described as early as in 1928 by Kozłowska [24] and it verified 
by Medwecka-Kornaś in 1959 [19]. Kozłowska [24] reported this community from the villages of Chotel Czerwony, Skorocice, and Aleksandrów in the Nida Basin of the Małopolska Upland. Medwecka-Kornaś [19] confirmed the occurrence of this community at the two first sites, and additionally recorded its presence in Winiary. The association only appeared in small patches, on the steep and exclusively northern (north-eastern, north-western) slopes of gypsum hills. The patches have developed on humic rendzinas [19]. The few other localities of this association, however without phytosociological documentation, were reported by Medwecka-Kornaś [25] and Łuszczyński and Łuszczyńska [26] from the Nida Basin. All sites of the Seslerio uliginosae-Scorzoneretum purpureae association known up to the 1950s were enclosed in areas designated xerothermic nature reserves. Towpasz and Stachurska-Swakon found new localities of this rare association during field studies in the Nida Basin in years 2009-2010 [27]. The patches were recorded in the surrounding of the villages of Sielec, Skotniki, Sułkowice, and Wiślica. The exclusive occurrence of Sesleria uliginosa (against S. caerulea) on the area of the Nida Basin was confirmed on the base of cytological and taxonomical studies [19,27,28].

The aim of this paper is to assess the possibility of maintaining the xerothermic grasslands with Sesleria uliginosa in the light of the changes that have occurred since the first description of this community.

\section{Material and methods}

The phytosociological materials used for the study came from three periods: (i) 1920s - the first description of the community by Kozłowska [24] (5 relevés); (ii) 1950s - study of Medwecka-Kornaś [19] (7 relevés); (iii) 2009-2010 - study of Towpasz and Stachurska-Swakoń [27] (11 relevés).

As the association develops in small patches in very distinctive habitat conditions (northern slopes of gypsum hills in the Nida Basin) and according to available descriptions of the sites, it is highly probable that the relevés were made in the same localities. In the presented study the authors decided to include also a few relevés made by them that originated from other localities; namely nature reserves dedicated to xerothermic vegetation (Fig. 1). The phytocoenoses have a similar character in terms of habitat conditions, management and species composition [27]. Generally, the analysed relevés come from the following nature reserves: "Przęślin", "Skorocice", "Winiary" $[19,24,27]$ and "Góry Wschodnie", "Krzyżanowice", "Skotniki Górne", and "Skowronno" [27].

The similarities between relevés were calculated using the UPGMA classification with cover-abundance values (Ružicka coefficient) and the SYNTAX 2000 software package [29]. Detrended Correspondence Analysis (DCA, MVSP, [30]) was applied with the cover-abundance values, in order to define the main dynamic tendencies along the time gradient. Correlations between DCA axes and selected variables measured for individual relevés were calculated using Kendal's rank correlation coefficient [31].

The synoptic table was made for three periods with constancy degree (frequency of every species occurrence, $S$ ) and index of coverage $(D)$, that was calculated as total of the mean percentages of coverage of the given species in all relevés, divided by the total number of relevés and multiplied by 100 [32]. The value of that index is independent of the number

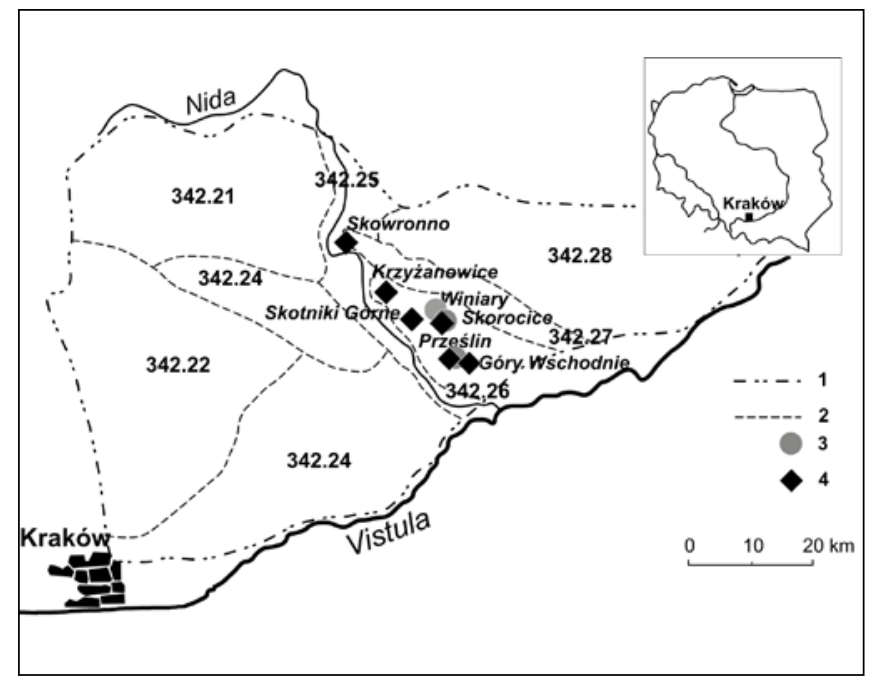

Fig. 1 Location of studied phytocoenoses of Seslerio-Scorzoneretum in the Nida Basin, the Małopolska Upland. 1 - border of the Nida Basin; 2 - borders of physiographical units after Kondracki [56]: 342.21 - Jędrzejów Plateau, 342.22 - Miechów Upland, 342.23 - Proszowice Basin, 342.24 - Wodzisław Hummock, 342.25 - Nida Valley, 342.26 - Solec Basin, 342.27 - Pińczów Hummock, 342.28 - Połaniec Basin; 3 - relevés made in 1920s, 1959s; 4 - relevés made in 2010.

of relevés and together with the constancy degree and abundance, give a good estimation of the role of species in the communities. The diagnostic value of species follows the work of Medwecka-Kornaś [19], Medwecka-Kornaś et al. [33], and Matuszkiewicz [34].

A total and mean number (per relevé) of diagnostic species from the syntaxonomical units (Cirsio-Brachypodion pinnati, Festucetalia valesiacae, Festuco-Brometea, Trifolio-Geranietea, Molinio-Arrhenatheretea, Quercetalia pubescentis) were calculated for each time period. Additionally, the species were divided into the following functional groups: forbs, grasses, and mosses. In order to characterize the environmental preferences of the species composing the phytocoenoses in different time periods, mean ecological indicator values were calculated (light, moisture, reaction, nitrogen; [35]). Diversity indices (the Shannon-Wiener and evenness index) were calculated using the MVSP software [30]. To estimate the statistical significance of differences between the characteristics of three research periods, the non-parametric Kruskal-Wallis test was used.

The nomenclature of vascular plants follows Mirek et al. [36], the nomenclature of bryophytes follows Ochyra et al. [37].

\section{Results}

The contemporary field studies approve the distinctiveness and rarity of the Seslerio-Scorzoneretum purpureae association in the Nida Basin. The xerothermic grasslands with Sesleria uliginosa have always been found on exposed northern, north-western and north-eastern slopes on gypsum hills. The association developed on small areas $\left(8-300 \mathrm{~m}^{2}\right)$, and was always well bordered with surrounding communities. Sesleria uliginosa was one of the dominant species and covered 40-60\% of the phytocoenosis. It was accompanied by: Adonis vernalis, Avenastrum pratense, Brachypodium pinnatum, Campanula sibirica, Thesium linophyllon, Peucedanum oreoselinum and Salvia pratensis (Tab. 1). 
The UPGMA dendrogram revealed three clusters of relevés that correspond with the time of relevés origin (Fig. 2). The results indicate a higher similarity between groups of relevés from the 1920s and 1950s, when these areas were managed (probably grazed), as compared to relevés from 2010. Additionally, considering the level of similarity within groups, the similarity coefficients are highest among relevés from the 1920s and lowest among relevés from 2010.

While comparing the relevés made in the 1950s with the present-day, changes in the floristic composition of the Seslerio-Scorzoneretum purpureae association can be recorded. The most striking is the smaller number of xerothermic species occurring in particular phytocoenoses (Tab. 1, Tab. 2 and Tab. 3). Out of eight species diagnostic of the association, only Sesleria uliginosa remained with a similar cover. Other diagnostic species became rare, especially, Scorzonera purpurea which seldom occurred in the patches. The visible changes in floristic composition concern the group of species diagnostic of the Festucetalia valesiacae order and the Festuco-Brometea class. Many species, once common, no longer occur, such as Campanula glomerata, Scabiosa canescens, Veronica spicata. Some taxa, such as Astragalus danicus were less frequent. Overall, the total number of species diagnostic of the FestucoBrometea class changed from 56 in the 1950s to 46 in 2010 (Tab. 2). The changes also concerned the Trifolio-Geranietea species. We did not find Anemone sylvestris, and other taxa were less frequent. The differences in the diagnostic species of xerothermic grasslands were statistically significant over the study period (Tab. 3). It is worth noting an increase of grasses in contemporary phytocoenoses in terms of number of species, degree of cover and index of coverage (Tab. 1, Tab. 2). To the group with a markedly higher coverage index belong: Avenula pratensis, Brachypodium pinnatum, Briza media and Dactylis glomerata. At the same time, the role of mesophilous species has increased recently as they were characterised by a higher index of coverage. Additionally, single specimens of shrubs (Crataegus sp., Frangula alnus) were noted in the contemporary patches of phytocoenoses.

A considerable reduction was apparent in the bryophytes layer. The mosses profusely covered the patches (40-60\%) and their occurrence was regarded as a characteristic feature of the association. Currently, the coverage of mosses does not exceed 10\%. Abietinella abietina, Homalothecium lutescens or Thuidium phillibertii were among the species now absent.

Diversity indices decreased between 1950 and 2010 (Tab. 3). The number of species recorded in the last period in a single patch was smaller, while at the same time, the cover of the herbaceous layer was higher when compared to the 1950s. The mean indicator value for nitrogen increased with statistical significance, whereas the indicator value for reaction decreased between 1950s and 2010 .

The diagram of the DCA showed three groups of relevés as revealed by the 1st Axis. These groups of relevés correspond to the time of their origin (Fig. 3).

Relevés made in the 1920s and in 2010 are located at the opposite ends of the 1st Axis. The diagram also points to the higher homogeneity within the relevés from 1920s and the considerably lower levels present in the relevés from 2010. The indicator of the Festuco-Brometea species was most strongly correlated with the 1st DCA Axis (Tab. 4). The only statistically significant correlation with the 2 nd Axis was a variable representing the value of the nitrogen indicator.

Tab. 1 The synoptic table of Seslerio uliginosae-Scorzoneretum purpureae from 1920 to 2010 in the Nida Basin.

\begin{tabular}{cccccc}
\multicolumn{2}{c}{ A } & \multicolumn{2}{c}{ B } & \multicolumn{2}{c}{ C } \\
\hline$S$ & $D$ & $S$ & $D$ & $S$ & $D$
\end{tabular}

\author{
Ch. $\left({ }^{*}\right)$, D. Ass. Seslerio uliginosae- \\ Scorzoneretum purpureae \\ Sesleria uliginosa \\ Galium boreale (reg.) \\ ${ }^{*}$ Asperula tinctoria \\ * Viola rupestris \\ * Scorzonera purpurea \\ Valeriana angustifolia \\ * Thalictrum simplex
}

Ch. All. Cirsio-Brachypodion pinnati

Veronica austriaca

Campanula sibirica

Elymus hispidus

Senecio integrifolius

Seseli annuum

Inula ensifolia

Melampyrum arvense

Carex flacca

\section{Ch. O. Festucetalia valesiaceae}

Adonis vernalis

Astragalus danicus

Thesium linophyllon

Thymus austriacus

Thymus kosteleckyanus

Erysimum odoratum

Potentilla arenaria

Scabiosa ochroleuca

Thymus glabrescens

Achillea pannonica

Onobrychis arenaria

Ornithogalum collinum

Bromus inermis

Salvia verticillata

Stipa joannis

Galium valdepilosum

Hieracium bauhinii

Ch. Cl. Festuco-Brometea

Euphorbia cyparissias

Salvia pratensis

Filipendula vulgaris

Trifolium montanum

Centaurea scabiosa

Polygala comosa

Carex humilis

Brachypodium pinnatum

Anthyllis vulneraria

Plantago media

Avenula pratensis

Dianthus carthusianorum

Scabiosa canescens

Festuca rupicola

Arabis hirsuta

Ranunculus bulbosus

Campanula glomerata

$\begin{array}{cccccc}\text { V } & 2300 & \text { V } & 3143 & \text { V } & 3909 \\ \text { V } & 750 & \text { V } & 717 & \text { II } & 136 \\ . & . & \text { V } & 2536 & \text { I } & 318 \\ \text { V } & 1000 & \text { IV } & 326 & . & . \\ \text { III } & 202 & \text { III } & 144 & \text { I } & 1 \\ . & . & \text { III } & 74 & \text { I } & 46 \\ \text { I } & 2 & \text { III } & 4 & . & .\end{array}$

$\begin{array}{cccccc}\text { IV } & 204 & \text { IV } & 77 & \text { I } & 1 \\ \text { III } & 202 & \text { III } & 6 & \text { II } & 3 \\ . & . & \text { III } & 76 & . & . \\ . & . & \text { III } & 6 & \text { I } & 46 \\ \text { V } & 206 & \text { III } & 76 & . & . \\ . & . & \text { II } & 894 & \text { I } & 682 \\ . & . & \text { I } & 1 & \text { III } & 94 \\ . & . & . & . & \text { II } & 206\end{array}$

$$
\begin{aligned}
& \text {. } \begin{array}{lllll}
\text { V } & \mathrm{V} & 79 & \mathrm{IV} & 95
\end{array} \\
& \begin{array}{llllll}
\mathrm{V} & 402 & \mathrm{~V} & 80 & \mathrm{I} & 2
\end{array} \\
& \text { III } 254 \text { IV } 1455 \\
& \text { III } 4 \\
& \text { III } 455 \\
& \begin{array}{llll}
\text { III } & 74 & \text { I } & 91
\end{array} \\
& \mathrm{~V} \quad 402 \text { III } 4 \text {. } \\
& \text { III } 4 \text { I } 1 \\
& \begin{array}{llll}
\mathrm{V} & 79 & \mathrm{I} & 1
\end{array} \\
& \text { III } 6 \\
& \text { III } 74 \\
& \text { III } 76 \\
& \text { II } 3 \text { I } 1 \\
& \text { II } 3 \text { I } 46 \\
& \text { II } 3 \text { I } 1 \\
& \text { III } 252 \\
& \text { II } 48
\end{aligned}
$$

$\begin{array}{cccccc}\text { V } & 500 & \text { V } & 9 & \text { IV } & 797 \\ \cdot & \cdot & \text { V } & 149 & \text { V } & 458 \\ \text { IV } & 302 & \text { V } & 716 & \text { IV } & 546 \\ \text { V } & 750 & \text { V } & 896 & \text { IV } & 639 \\ \text { IV } & 8 & \text { V } & 219 & \text { II } & 47 \\ \text { V } & 402 & \text { V } & 9 & \text { II } & 3 \\ \text { V } & 1402 & \text { V } & 2143 & \text { I } & 45 \\ . & . & \text { IV } & 644 & \text { V } & 1841 \\ \text { V } & 1500 & \text { IV } & 7 & \text { II } & 48 \\ \text { IV } & 302 & \text { IV } & 77 & \text { II } & 48 \\ \text { II } & 200 & \text { IV } & 147 & \text { III } & 683 \\ \text { IV } & 302 & \text { IV } & 77 & \text { III } & 138 \\ . & . & \text { IV } & 7 & . & . \\ \text { V } & 1900 & \text { II } & 73 & \text { IV } & 1364 \\ \text { V } & 10 & \text { III } & 4 & . & . \\ \text { V } & 402 & \text { III } & 74 & \text { II } & 3 \\ . & . & \text { III } & 144 & . & .\end{array}$


Tab. 1 (continued)

Phleum phleoides

Carex caryophyllea

Veronica spicata

Asperula cynanchica

Centaurea stoebe

Onobrychis viciifolia

Abietinella abietina $(\mathrm{ml})$

Hypnum cupressiforme (ml)

\section{Ch. Cl. Trifolio-Geranietea sanquinei}

Medicago falcata

Fragaria viridis

Thalictrum minus

Galium verum

Anemone sylvestris

Peucedanum cervaria

Veronica teucrium

Agrimonia eupatoria

Ch. Cl. Quercetalia pubescenti-petraeae

Primula veris

Viola hirta

Ch. Cl. Molinio-Arrhenatheretea

Dactylis glomerata

Galium mollugo

Lotus corniculatus

Leucanthemum vulgare

Knautia arvensis

Ranunculus acris

Leontodon hispidus

Others

Briza media

Peucedanum oreoselinum

Pimpinella saxifraga

Homalothecium lutescens $(\mathrm{ml})$

Thuidium phillibertii $(\mathrm{ml})$

Rhytidium rugosum (ml)

Fissidens taxifolius (ml)

Plagiomnium affine $(\mathrm{ml})$

IV $\quad 400 \quad \mathrm{~V} \quad 576 \quad$ I 46

$\begin{array}{cccccc}\text { II } & 200 & \text { II } & 3 & \text { II } & 92 \\ \text { III } & 300 & \text { II } & 3 & . & . \\ . & . & \text { II } & 3 & . & . \\ \text { V } & 206 & \text { I } & 1 & \text { III } & 795 \\ . & . & . & . & \text { II } & 48 \\ . & . & \text { I } & 1 & \text { III } & 5 \\ \text { V } & 652 & \text { V } & 826 & . & . \\ \text { V } & 10 & \text { II } & 3 & . & .\end{array}$

$$
\begin{array}{cccccc}
. & . & \text { V } & 150 & \text { III } & 95 \\
. & . & \text { V } & 9 & \text { III } & 411 \\
\text { III } & 202 & \text { IV } & 396 & \text { I } & 160 \\
\text { I } & 2 & \text { IV } & 256 & \text { II } & 205 \\
. & . & \text { IV } & 823 & . & . \\
. & . & \text { III } & 323 & \text { II } & 477 \\
. & . & \text { II } & 73 & \text { I } & 45 \\
. & . & \text { II } & 3 & \text { II } & 47
\end{array}
$$

$$
\begin{array}{cccccc}
\text {. } & \text {. } & \text { II } & 73 & \text {. } & \text {. }
\end{array}
$$

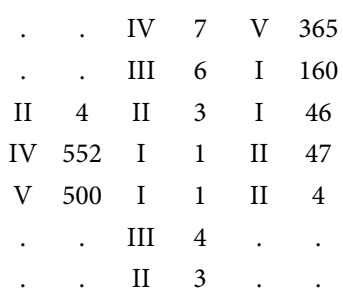

Source of relevés: A - 1920s [24]; B - 1950s [19]; C - 2010 [27]. D - index of coverage; $\mathrm{ml}$ - moss layer; reg. - regional; $S$ - constancy.

\section{Discussion}

Analysis of changes in the species composition revealed the process of slow succession, which is currently underway in the phytocoenoses of Seslerio uliginosae-Scorzoneretum purpureae. The species richness of the community has decreased. The diagnostic species of the association, Cirsio-Brachypodion pinnatii and Festucetalia valesiacae have either vanished or become less frequent. This process can be related to the lack of appropriate land use that was stopped or reduced, after the establishment of nature reserves. The majority of the steppe reserves in the area of the Nida Basin (like "Przęślin", "Winiary") was established in 1960. The steppe reserve "Skorocice" was under legal protection from 1947 but the area was used by

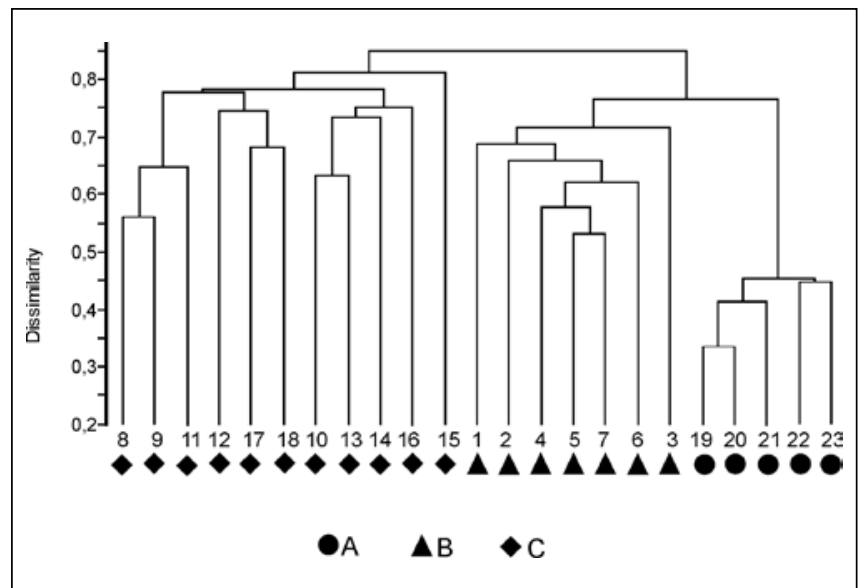

Fig. 2 UPGMA dendrogram based on cover-abundance scale (Ružicka coefficient) for relevés of Seslerio uliginosae-Scorzoneretum purpureae made between 1920 and 2010 in the Nida Basin: A - relevés made in 1920s; B - relevés made in 1950s; C - relevés made in 2010.

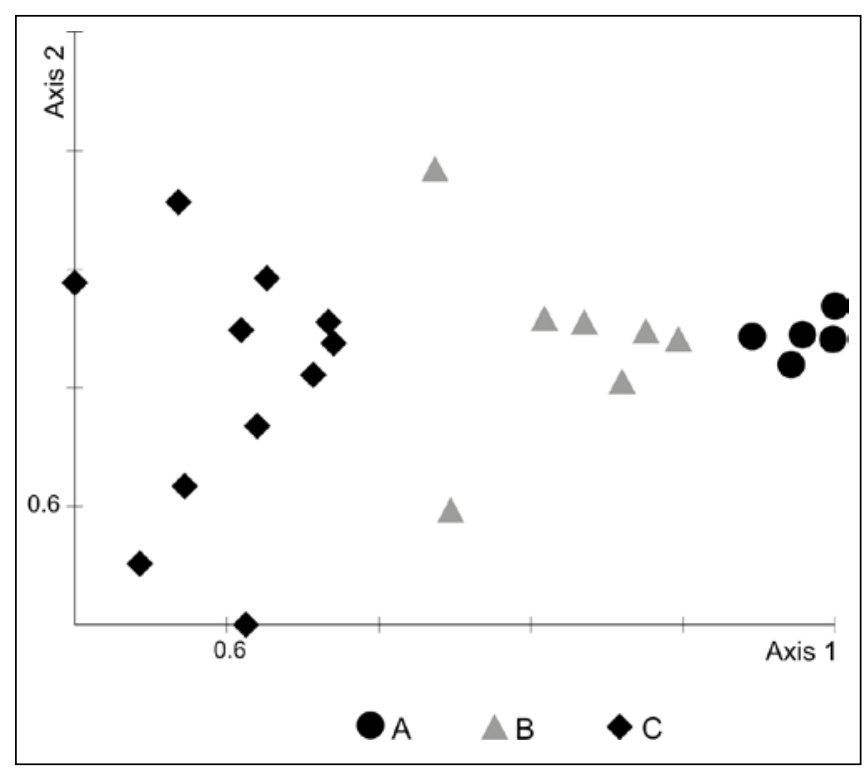

Fig. 3 Ordination of Seslerio uliginosae-Scorzoneretum purpureae relevés made between 1920 and 2010 along first two DCA axes (Axis $1=15.22 \%$, Axis $2=6.98 \%$ ). A - relevés made in 1920s; B - relevés made in 1950s; C - relevés made in 2010.

the local population until the late 1950s [19]. According to localities of the Seslerio-Scorzoneretum, it could be assumed that grazing is needed for maintaining the floristic composition of the patches, known from time the community was described. The succession of xerothermic grasslands, caused by lack of appropriate land use, has been observed in different parts of both Poland and Europe (e.g. [38-44]). As the xerothermic species are characterized by a transient seed bank [45-47], the lack of a suitable regeneration niche could lead to a reduced diversity of species. Various experiments have shown that for maintaining calcareous grassland, which has similar habitat conditions to gypsum grasslands, there is a need for different management practices such as grazing, mowing, formation of gaps or even sowing seeds [48-53]. The results of experimental grazing by goats and sheep on the Góra Zborów Nature Reserve (KrakówCzęstochowa Upland), highlighted the fact that hill grazing 
Tab. 2 Characteristics of the Seslerio uliginosae-Scorzoneretum purpureae from 1920 to 2010 in the Nida Basin.

\begin{tabular}{lccc} 
& A & B & C \\
\hline Number of relevés & 5 & 7 & 11 \\
Cover of herb layer (mean value, \%) & n.d. & 88 & 99 \\
Cover of moss layer (mean value, \%) & n.d. & 59 & 1 \\
Vascular plant species without grass & 45 & 87 & 74 \\
Grass species & 6 & 13 & 16 \\
Shrub species & 0 & 0 & 3 \\
Moss species & 7 & 11 & 4 \\
& & & \\
Diagnostic species groups & & & \\
Ch., D. Ass. Seslerio-Scorzoneretum & 5 & 7 & 5 \\
Ch. All. Cirsio-Brachypodion pinnati & 3 & 7 & 7 \\
Ch. All., O. Festucetalia valesiaceae & 5 & 15 & 14 \\
Ch. Cl. Festuco-Brometea & 18 & 26 & 21 \\
Ch. Cl. Trifolio-Geranietea & 2 & 11 & 12 \\
Ch. O. Quercetalia pubescentis & 3 & 3 & 2 \\
Ch. Cl. Molinio-Arrhenatheretea & 3 & 10 & 9 \\
Others & 14 & 31 & 25 \\
\hline
\end{tabular}

Values for species groups are given as total numbers. A - 1920s [24]; B - 1950s [19]; C - 2010 [27]. n.d. - lack of data.

Tab. 3 Mean values of characteristics of Seslerio uliginosae-Scorzoneretum purpureae in the Nida Basin in last 90 years.

\section{$\begin{array}{llllll}\text { A } & \text { B } & \text { C } & \boldsymbol{p}_{\mathrm{AB}} & \boldsymbol{p}_{\mathrm{AC}} & \boldsymbol{p}_{\mathrm{BC}}\end{array}$}

\begin{tabular}{lcccccc} 
Ellenberg indicator values & & & & & & \\
Light & 7.45 & 7.32 & 7.36 & $<0.01$ & $\mathrm{~ns}$ & $\mathrm{~ns}$ \\
Moisture & 3.01 & 3.08 & 3.18 & $\mathrm{~ns}$ & $\mathrm{~ns}$ & $\mathrm{~ns}$ \\
Reaction & 5.81 & 6.11 & 5.62 & $\mathrm{~ns}$ & $\mathrm{~ns}$ & $<0.05$ \\
Nitrogen & 2.03 & 2.37 & 2.60 & $<0.05$ & $<0.05$ & $<0.05$ \\
& & & & & & \\
Shannon index & 3.48 & 3.57 & 2.99 & $\mathrm{~ns}$ & $<0.01$ & $<0.01$ \\
Evenness index & 0.96 & 0.96 & 0.93 & $\mathrm{~ns}$ & $<0.01$ & $<0.05$ \\
Mean number of vascular plant & & & & & & \\
species & 44 & 50 & 26 & $\mathrm{~ns}$ & $<0.01$ & $<0.01$ \\
Mean number of mosses & 6 & 5 & 2 & $\mathrm{~ns}$ & $<0.01$ & $<0.01$ \\
Ch., D. Ass. Seslerio uliginosae- & & & & & & \\
Scorzoneretum purpureae & 6 & 6 & 2 & $<0.01$ & $\mathrm{~ns}$ & $<0.001$ \\
Ch. All. Cirsio-Brachypodion pinnati & 2 & 3 & 2 & $\mathrm{~ns}$ & $\mathrm{~ns}$ & $<0.05$ \\
Ch. O. Festucetalia valesiaceae & 4 & 8 & 4 & $<0.01$ & $\mathrm{~ns}$ & $<0.05$ \\
Ch. Cl. Festuco-Brometea & 15 & 14 & 9 & $\mathrm{~ns}$ & $<0.01$ & $<0.01$ \\
Ch. Cl. Molinio-Arrhenatheretea & 2 & 3 & 2 & $\mathrm{~ns}$ & $\mathrm{~ns}$ & $\mathrm{~ns}$ \\
Ch. Cl. Trifolio-Geranietea sanquinei & 1 & 6 & 3 & $<0.01$ & $<0.05$ & $<0.05$ \\
Others & 12 & 9 & 4 & $\mathrm{~ns}$ & $<0.01$ & $<0.01$ \\
\hline & & & & & &
\end{tabular}

A - 1920s [24]; B - 1950s [19]; C - 2010 [27]. ns - statistically not significant; $p_{\mathrm{AB}}, p_{\mathrm{AB}}, p_{\mathrm{AC}}-$ probabilities on the base of Kruskall-Wallis test.
Tab. 4 Rank correlation (value of Kendall's $\tau$ ) between 1st and 2nd axis DCA and some variables of the Seslerio uliginosae-Scorzoneretum purpureae association.

\begin{tabular}{|c|c|c|}
\hline Variables & Axis 1 & Axis 2 \\
\hline Number of species & $0.536^{\star * *}$ & 0.075 \\
\hline Cover of herb layer & $-0.621^{* * *}$ & -0.161 \\
\hline Cover of moss layer & $0.584^{\star * *}$ & 0.009 \\
\hline \multicolumn{3}{|l|}{ Ellenberg indicator values } \\
\hline Light & 0.091 & -0.265 \\
\hline Moisture & -0.259 & 0.211 \\
\hline Reaction & 0.051 & 0.091 \\
\hline Nitrogen & $-0.515^{\star * *}$ & $0.237^{*}$ \\
\hline Shannon index & $0.581^{\star * *}$ & 0.083 \\
\hline Evenness index & $0.549^{* * *}$ & 0.087 \\
\hline \multicolumn{3}{|l|}{ Diagnostic species group } \\
\hline Ch., D. Ass. Seslerio uliginosae-Scorzoneretum & $0.651^{\star * *}$ & 0.182 \\
\hline Ch. All. Cirsio-Brachypodion pinnati & 0.168 & 0.245 \\
\hline Ch. O. Festucetalia valesiaceae & $0.303^{*}$ & 0.045 \\
\hline Ch. Cl. Festuco-Brometea & $0.666^{\star * *}$ & 0.012 \\
\hline Ch. Cl. Molinio-Arrhenatheretea & 0.141 & 0.049 \\
\hline Ch. Cl. Quercetalia pubescenti-petraeae & $0.449^{* *}$ & -0.071 \\
\hline Ch. Cl. Trifolio-Geranietea sanquinei & -0.021 & 0.248 \\
\hline Others & $0.657^{\star * *}$ & -0.033 \\
\hline
\end{tabular}

${ }^{\star} 0.01<p<0.05 .{ }^{\star *} 0.001<p<0.01 .{ }^{\star * *} p<0.001$.

creates favourable conditions for plants and animals typical of xerothermic grasslands [48].

As in the presented study, an increase in the cover of high grasses and some perennials during the succession of calcareous grasslands is often reported $[38,39,44]$. The fast expansion of these species linked with excessive fertilisation of grasslands with nitrogen compounds from the air, is regarded as one of the principal causes of the reduction of the richness of the calcareous grasslands [54]. On the other hand, species with extended vegetative spread have a greater chance to develop and dominate the vegetation. The presence of these plants through the type of growth and development of thick felt, as well as the phenomenon of allelopathy, bring about the reduced possibility of germination for other species. In particular, the calcareous species have difficulty germinating and establishing themselves in thick litter layer and dense vegetation. Very helpful in the formation of gaps are animals such as goats or sheep.

In the course of succession in the old grasslands, the increase in number and coverage of shrubs is usually reported (e.g. [44,49]). Their occurrence often causes a series of changes in species composition. The high density of shrubs result in herb layer being overshadowed, which prevent heliophilous xerothermic species from penetrating and becoming established in such places. However, in our study only single specimens of shrubs were observed. This result could be connected with the conditions of habitats where phytocoenoses of SeslerioScorzoneretum occur. The shallow soil layer on the northern, rather steep slopes on gypsum hills, and the long distance from source of shrub and tree seeds, could be the reason for the slow establishment of shrubs and trees. Specific chemical 
and moisture features of gypsum soils are likely to inhibit the growth of tree and shrub seedlings [19]. The significance of soil thickness for maintaining species richness in calcareous grasslands was stressed [38]. Strong influence of climatic conditions, such as temperature or precipitation during the early spring period, was reported in studies where small changes in calcareous grasslands were observed [55].

Our results suggest that without appropriate management, we could expect the change of Seslerio-Scorzoneretum purpureae to mesophilous grasslands with a dominance of tall grasses and forbs. However, Sesleria uliginosa does not seem to be a threatened species. The occurrence of this grass creating dense tussocks is highly connected with the presence of calcium in the substratum, whereas the moisture conditions are not a limitation for the species. It is believed that Sesleria uliginosa belong to the "core species" of the described community, with the tussock form and slow rate of growth.

\section{Acknowledgements}

We thank Prof. Anna Medwecka-Kornaś, Dr hab. Józef Mitka and two anonymous reviewers for their insightful comments on the earlier versions of this manuscript.

\section{References}

1. Hultén E, Fries M. Atlas of North European vascular plants: north of the Tropic of Cancer. Königstein: Koeltz; 1986. (vol 1).

2. Čeřovský J, Feráková V, Holub J, Maglocký Š, Prochazká F. Cervená kniha ohrozených a vzácnych druhov rastlín a zivocíchov SR a CR. Vyššie rastliny. Bratislava: Príroda; 1991. (vol 5).

3. Witkowski ZJ, Król W, Solarz W, editors. Carpathian list of endangered species. Vienna: WWF and Institute of Nature Conservation, Polish Academy of Sciences; 2003.

4. Zarzycki K, Szeląg Z. Red list of the vascular plants in Poland. In: Mirek Z, Zarzycki K, Wojewoda W, Szeląg Z, editors. Red list of plants and fungi in Poland. Kraków: W. Szafer Institute of Botany, Polish Academy of Sciences; 2006. p. 11-20.

5. Tímár G. Új florisztikai adatok a Soproni-hegységből. Soproni Szemle. 1996;50(4):348-356.

6. Válek P. Další příspěvek k poznaní ekologických poměrů porostů pěchavy bažinné (Seslerietum uliginosae Klika) v severovýchodních Čechách. Věst Král Čs Spol Nauk Cl Math-Nath. 1951;5:1-10.

7. Válek P. Půdní vlastnosti subasociací Seslerietum uliginosaeCaricetosum pulicaris a Molinietum coerulae-Caricetosum distantis u rybníku "Kopičák" u Chlumce n. Cidl. Preslia. 1959;31:14-19.

8. Hájek M, Háberová I. Scheuchzerio-Caricetea fuscae R. Tx. 1937. In: Valachovič M, editor. Vegetácia mokradí. Bratislava: Veda; 2001. p. 187-273. (vol 3).

9. Bosáčková E. Ochranársky výskum močiarných biocenóz Turčianskej kotliny (vegetačné pomery význačnejších lokalít). Čs Och Prír. 1974;14:59-102.

10. Škovirová K. Rastlinné spoločenstvá Kláštorských lúk a dolného toku Turca. Kmetianum. 1974;3:205-233.

11. Dítě D, Hájek M, Hájková P. Formal definitions of Slovakian mire plant associations and their application in regional research. Biologia. 2007;62(4):400-408. http:// dx.doi.org/10.2478/s11756-007-0082-8

12. Coldea GH. Prodrome des associations végétales des Carpates du sud-est (Carpates Roumaines). Documents Phytosociologiques, NS. 1991;13:317-539.

13. Hájek M, Hájková $P$, Apostolova I. New plant associations from Bulgarian mires. Phytol Balcan. 2008;14(3):377-399.

14. Wagner H. Das Molinietum caerulae (Pfeifengraswiese) im Wiener Becken. Vegetatio. 1949;2:128-165.

15. Dierßen K. Vegetation Nordeuropas. Stuttgart: Ulmer; 1996.

16. Trinajstić I. Nomenklaturno-sintaksonomska revizija asocijacije "Deschampsietum mediae illyricum" (Zeidler) H-ic 1963 u Hrvatskoj. Agronomski glasnik. 2004;6:401-411.

17. Škovirová K, Očka S. Floristický príspevok k Dielniciam pri Kláštore pod Znievom. Kmetianum. 2005;10:105-130.

18. Zając A, Zając M, editors. Atlas rozmieszczenia roślin naczyniowych w Polsce. Kraków: Laboratory of Computer Chorology, Institute of Botany, Jagiellonian University; 2001.

19. Medwecka-Kornaś A. Roślinność rezerwatu stepowego "Skorocice" koło Buska. Ochr Przyr. 1959;26:1-260.

20. Głazek T. Ctenidio molluscae-Seslerietum uliginosae Klika 1943 em. Głazek 1983 - a new association for Poland. Acta Soc Bot Pol. 1984;53(4):575-583.

21. Głazek T. Lipario-Schoenetum ferruginei - a new plant association. Fragm Flor Geobot. 1992;37(2):549-562.

22. Towpasz K, Stachurska-Swakoń A. Występowanie Sesleria uliginosa (Poaceae) w zbiorowiskach $\mathrm{z}$ rzędu Caricetalia davallianae na obszarze Niecki Nidziańskiej (Wyżyna Małopolska). Fragm Flor Geobot Polonica. 2009;16(2):305-316.

23. Babczyńska-Sendek B, Barć A. Zbiorowiska łąkowe z Sesleria uliginosa (Poaceae) w okolicach Włodowic koło Zawiercia (Wyżyna Śląsko-Krakowska). Fragm Flor Geobot Polonica. 2009;16(2):363-375.

24. Kozłowska A. Naskalne zbiorowiska roślin na Wyżynie Małopolskiej. Rozpr Wydz Mat-Przyr PAU A/B. 1928;67:325-373.

25. Medwecka-Kornaś A. Rezerwaty stepowe nad dolną Nidą. Chrońmy Przyr Ojcz. 1952;8(6):3-20.

26. Łuszczyńska B, Łuszczyński J. Godna ochrony roślinność kserotermiczna Łagiewnik koło BuskaZdroju w województwie kieleckim. Chrońmy Przyr Ojcz. 1989;45(3):30-35.

27. Towpasz K, Stachurska-Swakoń A. Występowanie Sesleria uliginosa (Poaceae) w murawach kserotemicznych (Festuco-Brometea) na terenie Niecki Nidziańskiej (Wyżyna Małopolska). Fragm Flor Geobot Polonica. 2011;18(2):321-330.

28. Bielecki E. Badania cytologiczno-systematyczne nad Oreochloa disticha Link., Sesleria uliginosa Opiz i S. calcaria Opiz. Acta Soc Bot Pol. 1955;24(1):145-162.

29. Podani J. SYN-TAX 2000. Computer programs for data analysis in ecology and systematics. User's manual. Budapest: Scientia Publishing; 2001.

30. Kovach WL. MVSP - a multivariate statistical package for Windows, ver. 3.1. Pentraeth: Kovach Computing Services; 2007.

31. Sokal RR, Rohlf FJ. Biometry: the principles and practice of statistics in biological research. New York: W. H. Freeman; 1981.

32. Pawłowski B. Composition and structure of plant 
communities and methods of their study. In: Szafer W, editor. The vegetation of Poland. Oxford: Pergamon Press, Polish Scientific Publishers PWN; 1966. p. 241-281.

33. Medwecka-Kornaś A, Kornaś J, Pawłowski B, Zarzycki K. Przegląd ważniejszych zespołów roślinnych Polski. In: Szafer W, Zarzycki K, editors. Szata roślinna Polski. Warszawa: Polish Scientific Publishers PWN; 1977. p. 279-297. (vol 1).

34. Matuszkiewicz W. Przewodnik do oznaczania zbiorowisk roślinnych Polski. Vademecum Geobotanicum. Warszawa: Polish Scientific Publishers PWN; 2005. (vol 3).

35. Zarzycki K, Trzcińska-Tacik H, Różański W, Szeląg Z, Wołek J, Korzeniak U. Ecological indicator values of vascular plants of Poland. Kraków: W. Szafer Institute of Botany, Polish Academy of Sciences; 2002. (Biodiversity of Poland; vol 2).

36. Mirek Z, Piękoś-Mirkowa H, Zając A, Zając M. Flowering plants and pteridophytes of Poland - a checklist. Kraków: W. Szafer Institute of Botany, Polish Academy of Sciences; 2002. (Biodiversity of Poland; vol 1).

37. Ochyra R, Bednarek-Ochyra H, Żarnowiec J. Census catalogue of Polish mosses. Kraków: W. Szafer Institute of Botany, Polish Academy of Sciences; 2002. (Biodiversity of Poland; vol 3).

38. Bąba W. The species composition and dynamics in wellpreserved and restored calcareous xerothermic grasslands (South Poland). Biologia, Bratislava. 2004;59(4):447-456.

39. Dzwonko Z, Loster S. Vegetation differentiation and secondary succession on a limestone hill in southern Poland. J Veg Sci. 1990;1(5):615-622. http://dx.doi. org/10.2307/3235567

40. Fischer M, Stöcklin J. Local extinctions of plants in remnants of extensively used calcareous grasslands 19501985. Conserv Biol. 1997;11(3):727-737. http://dx.doi. org/10.1046/j.1523-1739.1997.96082.x

41. Michalik S. Changes in xerothermic vegetation during the 20 years' secondary succession on the study area of Grodzisko in Ojców National Park. Prądnik. Prace Muzeum W. Szafera. 1990;2:43-52.

42. Waldon B, Rapacka-Gackowska A. Stan zachowania i problemy ochrony muraw kserotermicznych w dolinach Wisły i Noteci. In: Ratyńska H, Waldon B, editors. Ciepłolubne murawy w Polsce - stan zachowania i perspektywy ochrony. Bydgoszcz: Kazimierz Wielki University in Bydgoszcz Press; 2010. p. 110-127.

43. Ward LK. Management of grassland - scrub mosaics. In: Hillier SH, Walton DWH, Wells DA, editors. Calcareous grasslands: ecology and management. Bluntisham: Bluntisham Books; 1990. p. 134-139.

44. Dzwonko Z, Loster S. Changes in plant species composition in abandoned and restored limestone grasslands
- the effects of tree and shrub cutting. Acta Soc Bot Pol. 2008;77(1):67-75.

45. Kalamees R, Zobel M. The role of the seed bank in gap regeneration in a calcareous grassland community. Ecology. 2002;83(4):1017. http://dx.doi.org/10.2307/3071910

46. Grubb PJ. The maintenance of species-richness in plant communities: the importance of the regeneration niche. Biol Rev. 1977;52(1):107-145. http://dx.doi.org/10.1111/ j.1469-185X.1977.tb01347.x

47. Willems JH, Bik LPM. Restoration of high species density in calcareous grassland: the role of seed rain and soil seed bank. Appl Veg Sci. 1998;1(1):91-100. http://dx.doi. org/10.2307/1479088

48. Czylok A, Ślusarczyk M, Tyc A, Waga JM. Wypas zwierząt gospodarskich jako sposób czynnej ochrony krajobrazu i różnorodności biologicznej rezerwatu “Góra Zborów”. Prądnik. Prace Muzeum W. Szafera. 2010;20:185-196.

49. Barbaro L, Dutoit T, Cozik P. A six-year experimental restoration of biodiversity by shrub-clearing and grazing in calcareous grasslands of the French Prealps. Biodivers Conserv. 2001;10:119-135.

50. Dolek M, Geyer A. Conserving biodiversity on calcareous grasslands in the Franconian Jura by grazing: a comprehensive approach. Biol Conserv. 2002;104(3):351-360. http:// dx.doi.org/10.1016/S0006-3207(01)00200-2

51. Krasicka-Korczyńska E, Stosik T. Wpływ oddziaływań zooantropogenicznych na roślinność muraw kserotermicznych. In: Ratyńska H, Waldon B, editors. Ciepłolubne murawy w Polsce - stan zachowania i perspektywy ochrony. Bydgoszcz: Kazimierz Wielki University in Bydgoszcz Press; 2010. p. 80-94.

52. Michalik S, Zarzycki K. Management of xerothermic grasslands in Poland: botanical approach. Coll Phytosociol. 1995;24:881-895.

53. Pärtel M, Kalamees R, Zobel M, Rosén E. Restoration of species-rich limestone grassland communities from overgrown land: the importance of propagule availability. Ecol Eng. 1998;10(3):275-286. http://dx.doi.org/10.1016/ S0925-8574(98)00014-7

54. Willems JH, Peet RK, Bik L. Changes in chalk-grassland structure and species richness resulting from selective nutrient additions. J Veg Sci. 1993;4(2):203-212. http:// dx.doi.org/10.2307/3236106

55. Kammer PM. Developmental responses of sub-dominant grassland species to current weather conditions and their relevance for annual vegetation changes. Folia Geobot. 2002;37:185-204.

56. Kondracki J. Geografia Polski. Mezoregiony fizycznogeograficzne. Warszawa: Polish Scientific Publishers PWN; 1994. 